\title{
Nozokomiální methemoglobinemie
}

\author{
Jan Táborský', Martin Střelka', Marcela Káňová2, Zdeněk Kořístek³, Šárka Blahutová3, \\ Roman Černohorský', Tomáš Mičkal' \\ 'Interní oddělení Nemocnice Nový Jičín, a.s. \\ ${ }^{2}$ Klinika anesteziologie, resuscitace a intenzivní medicíny LF OU a FN Ostrava \\ ${ }^{3}$ Klinika hematoonkologie LF OU a FN Ostrava
}

Methemoglobinemie je vzácná porucha hemového železa, při které jsou atomy dvojmocného železa oxidovány na železo trojmocné. Trojmocné železo váže kyslík s daleko vyšší afinitou (posun disociační křivky doleva) a hemoglobin ztrácí svoji schopnost transportovat kyslík do tkání. $V$ článku je prezentována kazuistika pacientky s methemoglobinemií nejasné příčiny, která se rozvinula za hospitalizace na JIP. Dále jsou v textu prezentovány možné přičiny methemoglobinemie a terapeutické možnosti tohoto život ohrožujícího stavu.

Klíčová slova: kyselina askorbová, lokální anestetika, methemoglobinemie, metylenová modř.

\section{Hospital-acquired methemoglobinemia}

Methemoglobinemia is rare condition of hem iron. Ferrous form iron $\left(\mathrm{Fe}^{2+}\right)$ is oxidised to Ferric form $\left(\mathrm{Fe}^{3+}\right)$. Methemoglobin has reduced ability to release oxygen to tissues and thereby leads to tissue hypoxia. We present case of patient with methemoglobinemia of unknown etiology. Methemoglobinemia developed during hospitalization. Diferent causes of methemoglobinemia and also a treatment possibilities are discussed.

Key words: ascorbic acid, local anesthetic, methemoglobinemia, methylene blue.

\section{Úvod}

Methemoglobinemie je vrozená či získaná porucha, při které je kation železa zvýšeně oxidován z železnatého $\left(\mathrm{Fe}^{2+}\right)$ na železitý $\left(\mathrm{Fe}^{3+}\right)$. Tím se hemoglobin mění na methemoglobin, který má výrazně vyšší afinitu ke kyslíku. Dochází k posunu disociační křivky kyslíku doleva s následnou tkáňovou hypoxií. Strukturní změna také snižuje schopnost vázat kyslík, což snižuje jeho vazebnou kapacitu. Většina autorů uvádí jako patologickou koncentraci vyšší než $1 \%$ methemoglobinu v žilní krvi. V literatuře Ize však dohledat i cut off $2 \%$ (1).

\section{Kazuistika}

Na urologické oddělení okresní nemocnice byla príijata 60letá žena s uroinfektem. Pacientka byla do té doby sledována pouze $v$ nefrologické ambulanci pro membranózní glomerulonefritidu s nefrotickým syndromem (diagnóza stanovena biopsií ledviny v únoru roku 2017). $\checkmark$ minulosti byla na terapii kortikosteroidy a cyklosporinem s dobrým efektem, ale sama si léčbu opakovaně ukončila. Nyní medikovala pouze rosuvastatin, kyselinu acetylsalicylovou a fixní kombinaci perindopril/ indapapmid/amlodipin. Kouřila do 3 cigaret denně, alergická anamnéza byla negativní, stejně tak i v rodinné anamnéze jsme nenašli žádné pozoruhodnosti. Při príjmu byla pacientka hypotenzní (TK 85/60 mm Hg, puls $92 / \mathrm{min}$ ) a febrilní - teplota v axile byla $38,2^{\circ} \mathrm{C}$. Kromě bilaterálně pozitivního tapottement byl fyzikální nález chudý. Laboratorní nález kromě známek zánětu a počínajícího renálního postižení nevykazoval výrazné patologie: CRP (C-reaktivní protein) $407 \mathrm{mg} /$, leukocyty 13,5×10\%/, urea

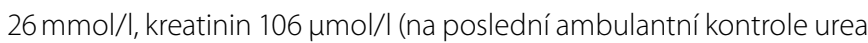
$8,29 \mathrm{mmol} / \mathrm{l}$, kreatinin 51 umol/l). Hemoglobin $99 \mathrm{~g} / \mathrm{l}$ odpovídal jejím chronickým hodnotám. V močovém sedimentu mimo vysoce pozitivní leukocyty i erytrocyty byly př́tomny i bakterie (gramnegativní tyčky). Nitrity byly negativní. Ultrazvukem byla vyloučena obstrukce urotraktu a byla zahájena terapie cefotaximem $1 \mathrm{~g}$ à 8 hod a balancovanými krystaloidy. Navzdory uvedené léčbě se stav pacientky zhoršil, došlo k progresi hypotenze a anurii. Proto byla pacientka následující den přeložena na interní JIP k další péči. 
Při přijmu na JIP pacientka tlakově hraniční (TK 105/60 mm Hg, puls 78/min), subfebrilní $\left(37,1^{\circ} \mathrm{C}\right)$ a kromě nově zjištěného šelestu nad aortální chlopní je i fyzikální nález shodný s príijmem z urologie. Laboratorně je lehký pokles CRP (328 mg/l), prokalcitonin je vysoký $(25,8$ mg/l), laktát jen lehce elevovaný $(3,2 \mathrm{mmol} / \mathrm{l})$. Pacientka byla nadále hydratována a pro prohloubení hypotenze bez reakce na volumovou výzvu byly nasazeny vazopresory. Navzdory obnovení perfuzního tlaku nedošlo k restartování diurézy, proto byla 4. den zahájena kontinuální dialýza (continual renal replacement therapy - CRRT) v režimu CVVHD (kontinuální veno-venózní hemodialýza) s regionální citrátkalciovou koagulací. Při této terapii se stav pacientky stabilizoval, vazopresory jsme vysadili a 7. den byla ukončena CRRT s obnovením diurézy. Desátý den hospitalizace došlo ke skokovému zhoršení stavu. Pacientka byla apatická, lehce cyanotická, v laboratorních nálezech dominovala nově hemolytická anémie ( $\mathrm{Hb} 67 \mathrm{~g} / \mathrm{l}$, bilirubin $92 \mu \mathrm{mol} / \mathrm{l}$, z toho konjugovaný 61 umol/l, LD (laktátdehydrogenáza) $36 \mu \mathrm{kat} / \mathrm{l}$, trombocyty $100 \times 10^{9} / \mathrm{I}$ - pokles z $220 \times 10^{\circ} /$, INR (mezinárodní normalizovaný poměr, international normalized ratio) 1,3, aPTT ratio (aktivovaný parciální tromboplastinový čas, activated parcial tromboplastine time) 1,2, antitrombin 124\%). Ostatní laboratorní markery hemolýzy, např. haptoglobin, hemopexin či volný hemoglobin, nebylo možno „ve službě“ vyšetřit. Jako prríčina deteriorace bylo zvažováno onemocnění ze skupiny mikroangiopatických hemolytických anémií (MAHA), postupně jsme však vyloučili diseminovanou intravaskulární koagulaci, trombotickou trombocytopenickou purpuru, hemolyticko-uremický syndrom i heparinem indukovanou trombocytopenii. V odpoledních hodinách progredovala cyanóza až hnědé zbarvení kưže navzdory oběhové stabilitě a jinak normálnímu nálezu při fyzikálním vyšetření. Proto jsme pojali podezření na methemoglobinemii, která byla následně potvrzena laboratorně (MetHb 30\%). V prvé fázi bylo podáno $5 \mathrm{~g}$ kyseliny askorbové (bez efektu na hladinu MetHb) a následně opakovaně transfuze. Pro postupné zhoršování stavu vědomí byla pacientka zaintubována a napojena na umělou plicní ventilaci (režim BiPAP, PEEP $4 \mathrm{~cm} \mathrm{H}_{2} \mathrm{O}, \mathrm{FiO}_{2}$ 0,40, dechový objem kolem $400 \mathrm{ml}$ ). $\mathrm{S}$ další deteriorací stavu byla později $\mathrm{FiO}_{2}$ zvyšována až na 1,0 ve snaze o využití hypersaturované plazmy jako nosiče kyslíku. Jako antidotum jsme podali metylenovou modř (methylthioninii chloridum, Proveblue) v dávce 100 mg, kterou jsme s odstupem $2 \mathrm{~h}$ zopakovali. Ani pres opakované podání antidota však nedocházelo k poklesu MetHb, proto jsme od dalšího podávání metylenové modři ustoupili. Kromě čistě logistických potíži (omezené zásoby antidota a nutnost jeho dovozu z centrálního skladu antidot) nás k změně terapeutického postupu vedla i progredující hemolýza, která mohla být jak př́ičinou selhání metylenové modři, tak i jejím nežádoucím účinkem.

Po vyčerpání konvenčních terapeutických postupů (podání metylenové modři a kyseliny askorbové) jsme opakovali podání transfuzí a pro riziko hypervolemie a hypervizkózního syndromu jej doplnili venepunkcemi (výsledné zbarvení kủže a sklér Obr. 1 a 2).

Jedenáctý den hospitalizace byla pacientka přeložena na KARIM spádové fakultní nemocnice. Při príijmu je stav pacientky kritický. Pacientka má hnědočerně zbarvenou kůži, je mírně prosáklá, s krvácivými projevy z dutiny ústní, nosní, krvácí ze vstupů. Bulby jsou ve středním postavení, bělmo je také zabarveno dohněda, zornice se jeví izokorické, miotické. Oběhově je nestabilní, noradrenalin v dávce $2 \mathrm{mg} /$ hod (vstupní laboratoř: pH 7,01, laktát 9,1 mmol/l, kalemie 6 mmol/l, MetHb $35 \%$, trombocyty $39 \times 10 \% /$, současně i vysoké parametry zá-

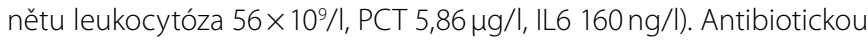
terapii eskalujeme na linezolid, meropenem. Ihned zahajujeme ve spolupráci s Klinikou hematoonkologie a Krevním centrem terapeutickou výměnnou erytrocytaferézu, při které bylo podáno 14 ERD, což odpovídalo 1,5násobku celkového objemu erytrocytů v krevním oběhu. Hladiny methemoglobinu však dostatečně neklesají ze vstupních $35 \%$ na 10\%. Opakovaně je nutná korekce vnitřního prostředí. Vzhledem k hemolytickému stavu po ukončení erytrocytaferézy jsme navázali s plazmaferézou ( $8 \times$ FFP, došlo tedy k výměně celého objemu plazmy) a dále pro anurii v šokovém stavu kontinuální dialýzou. Přes provedenou erytrocytaferézu kritický stav pacientky progreduje a následně zmírá během dalších $24 \mathrm{~h}$ pod obrazem refrakterního šoku.

Přes veškerou snahu o identifikaci príčiny methemoglobinmie jsme $v$ tomto směru nebyli úspěšní. Z níže uváděných léků, které mohou methemoglobinemii způsobit (Tab. 1), dostala pacientka $30 \mathrm{ml}$ 1\% roztoku trimecainu (Mesocain) s.c. při zavádění cévních vstupů. Proti lokálním anestetikům (LA) jako spouštěčům methemoglobinemie u naší pacientky svědčí delší časový odstup od aplikace léků. K příznakům methemoglobinemie by mělo dojít během několika desítek minut, nikoliv v odstupu 5 dní od podání. Další príčinou by mohla být kontaminace dialyzačního roztoku. Avšak na téže šarži roztoků byla paralelně dialyzovaná druhá pacientka v kritickém stavu, u které se methemoglobinemie nerozvinula (methemoglobin byl opakovaně vyšetřen na bed-side analyzátoru v rámci odběrů při CRRT s regionální citrátkalciovou antikoagulací, je součástí panelu na ABR z tepny). Teoreticky mohla vést k rozvoji methemoglobinemie i nastupující sepse s nadprodukcí oxidu dusnatého jako výrazného oxidačního činidla pro hemoglobin.

Stejně jako spouštěč, zůstává nejasná i velmi špatná terapeutická odezva. Selhání terapií kyselinou askorbovou lze vysvětlit její nízkou dávkou. Jako možná prǐčina selhání terapie metylenovou modří připadá v úvahu nepoznaný enzymatický deficit pentozafosfátové dráhy (ovšem u deficitu glukóza 6-fosfát dehydrogenázy (G6PD), který je vázaný na $X$ chromozom, je existence homozygotky $v$ české populaci extrémně nepravděpodobná, nicméně jej vyloučit zcela nelze. Deficit G6PD nebyl za časových důvodů vyšetřen). Účinek metylenové modři je závislý na intaktních erytrocytech, u hemolýzy selhává (1). Důsledkem těžké methemoglobinemie může být právě probíhající intravaskulární hemolýza, tzv. methemoglobinem-indukovaná hemolýza. V uveřejněných kazuistikách je nejčastěji vyvolána aromatickými aminosloučeninami (nitrobenzen, anilin), čínská review uvádí 1146 prípadů, kdy intravaskulární hemolýza vedla k renálnímu i jaternímu selhání, ale v 98 \% byla kurabilní (2). Avšak př́čina perzistující methemoglobinemie po provedené erytrocytaferéze je málo častá. Podobnou kazuistiku získané methemoglobinemie s hladinou metHb 82,3\%, nicméně u mladého muže, kde byla stejně jako v našem prípadě léčba metylenovou modří, kyselinou askorbovou, hyperbaroxií a erytrocytaferézou neúspěšná, vyprovokovala expozice aminofenolu. Podobnost je i v rozvoji intravaskulární hemolýzy. V důsledku chronickému vystavování se sloučenině podobné anilinu došlo k rozvoji trombotické mikroangiopatie (mikroangiopatická hemolýza, 
E48 | KAZUISTIKA

Nozokomiální methemoglobinemie

Obr. 1. Barva kůže pacientky prì MetHb 44,6\%

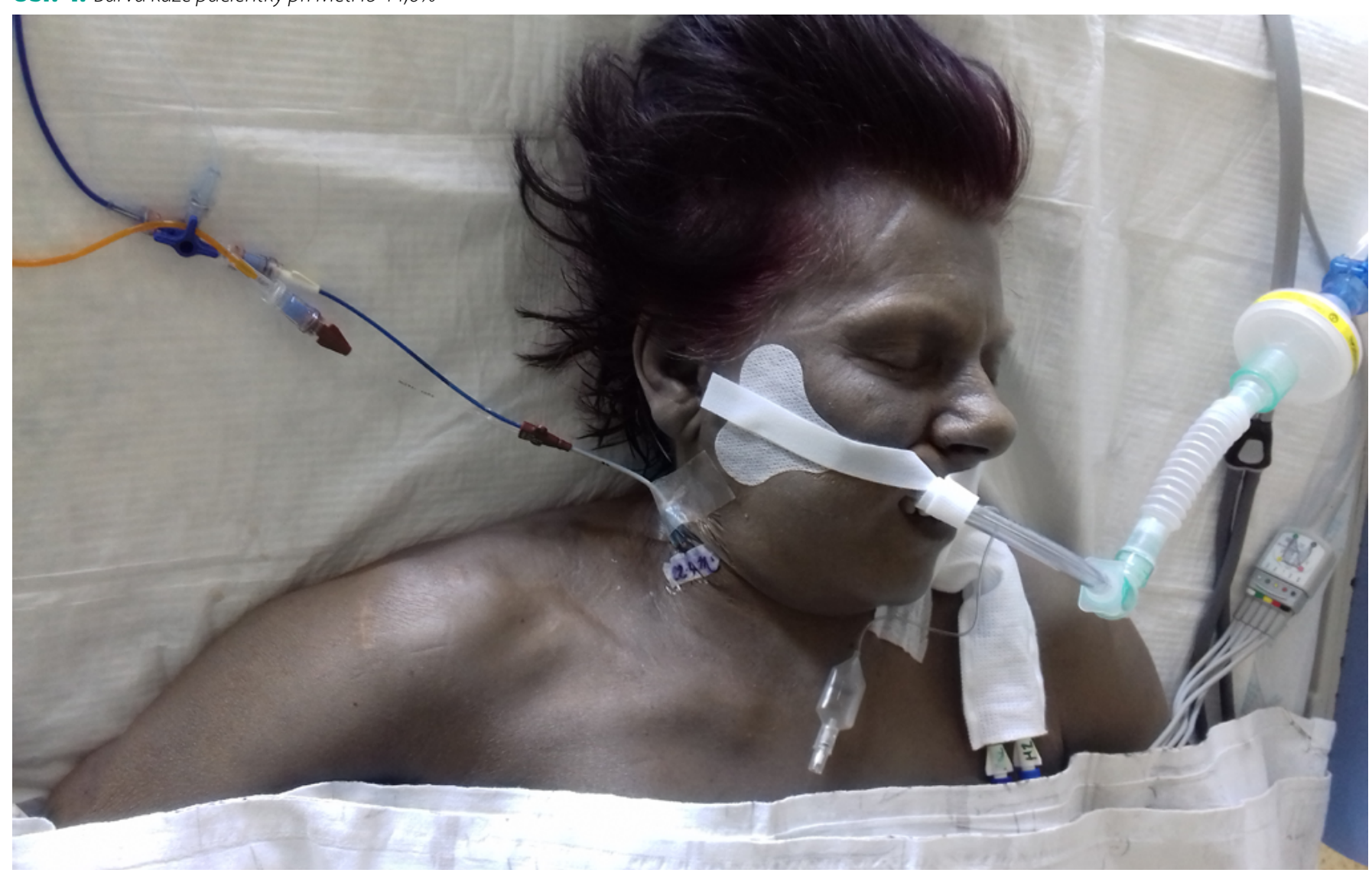

Obr. 2. Barva sklér pacientky prì MetHb 44,6\%

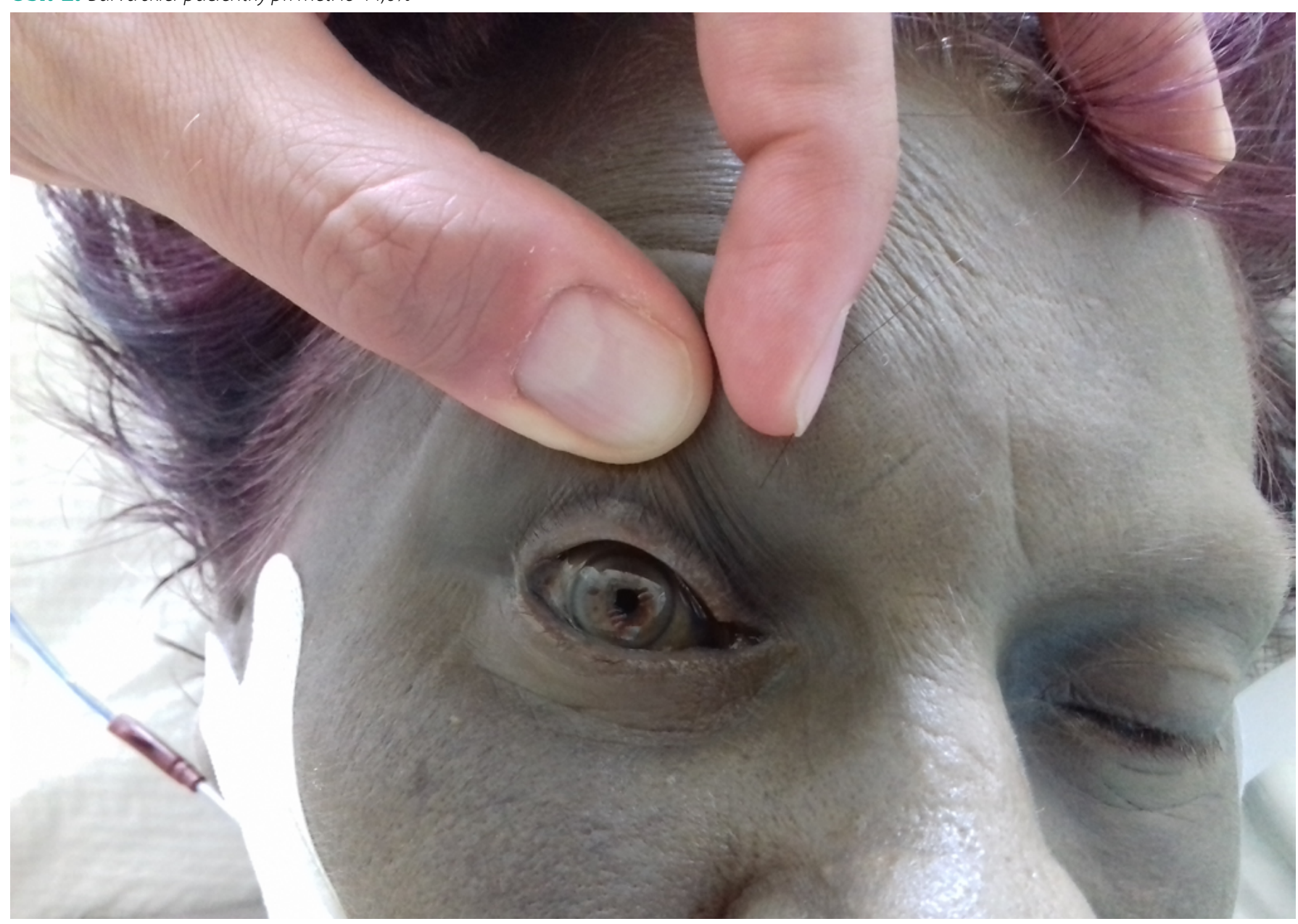


elevace LDH, trombocytopenie, oligurie). $V$ prrípadě popisovaném danou kazuistikou však pacient prežil. Ke zlepšování stavu došlo až po nasazení výměnné plazmaferézy (methemoglobin pozvolna klesal, bylo nutno opakování plazmaferézy v 6 následujících dnech). Plazmaferéza přerušila „začarovaný kruh" mezi methemoglobinem-indukovanou hemolýzou, endoteliální dysfunkcí a další hemolýzou. Volný hemoglobin vyvazuje oxid dusný z endotelu, následuje vazoparalýza, zvýšená agregace trombocytů (3).

\section{Methemoglobinemie}

Hemoglobin je metaloprotein vyskytující se v červených krvinkách v průměrném množství 28-32 pg na jeden erytrocyt. Jeho hlavním úkolem je transport kyslíku z plic do tkání. Pro plnění transportní funkce je nezbytné, aby železo v hemu bylo dvojmocné (Fe $\left.{ }^{2+}\right)$. Pouze dvojmocné železo může vázat a následně uvolňovat kyslík dle aktuálního $\mathrm{pO}_{2}$. V důsledku neustálého pưsobení oxidačních činidel dochází v těle $k$ permanentní přeměně $\mathrm{Fe}^{2+}$ na $\mathrm{Fe}^{3+}$ (a tím k vzniku methemoglobinu). Hladina methemoglobinu je však v důsledku redukční kapacity organismu neustále udržována velmi nízká (do 1-3\%) Pokud hladina methemoglobinu překročí $1 \%$, je stav označován jako methemoglobinemie.

U člověka je hemové železo chráněno před oxidací NADHmethemoglobinreduktázou (někdy označovanou jako cytochrom b5 reduktáza) a NADPH-methemoglobinreduktázou. Pro jejich správnou činnost jsou nezbytné kofaktory NAHD a NADPH, na jejichž produkci se podílí enzymy pyruvátkináza a G6PD (Obr. 4). I jejich deficit se tedy může projevit methemoglobinemií. Methemoglobinemie vzniká, pokud jsou enzymy deficitní či defektní (vrozená methemoglobinemie) nebo pokud je jejich redukční kapacita prekročena v důsledku působení toxinu (získaná methemoglobinemie).

\section{Hereditární methemoglobinemie}

Hereditární methemoglobinemie (recesive congenital methemoglobinemia - RCM) je vzácné autozomálně recesivně dědičné onemocnění způsobené deficitním enzymem NADH cytochrome b5 reduktázou. Jeho prevalence v běžné populaci je velmi nízká, nicméně přesná data nejsou dostupná. Jsou známé uzavřené populace, kde v důsledku príbuzenského křǐžení je prevalence vyšší. Příkladem mohou být Yakutové ze Sibiře, Athabaskové a indiáni z kmene Navajo.

RCM se vyskytuje v minimálně 4 typech, které se odlišují klinickými projevy a genetickým pokladem. Typ I je podmíněn mutací v genu CYB5R3, a kromě typického zbarvení kůže, které je patrné již od narození, nemá závažnější klinické projevy. U některých pacientů se mohou objevovat bolesti hlavy, únava a námahová dušnost. Typ II je asociován s mutací v Cb5R genu, projevuje se typickým kožním koloritem a závažnými neurologickými poruchami (mikrocefalie, mentální retardace, růstová retardace, strabismus). Typ III má stejný genetický defekt jako typ II, ale chybí neurologické projevy. Typ IV je velmi vzácný, projevuje se pouze kožními projevy.

Další př́činou vrozené methemoglobinemie je výskyt abnormálního hemoglobinu, nejčastěji jde o hemoglobin M, v jehož molekule byl tyrosin zaměněn za histidin, což snižuje redukci železitého na železnatý
Schéma 1. Patofyziologické cesty redukce methemoglobinu. Upraveno dle (4)

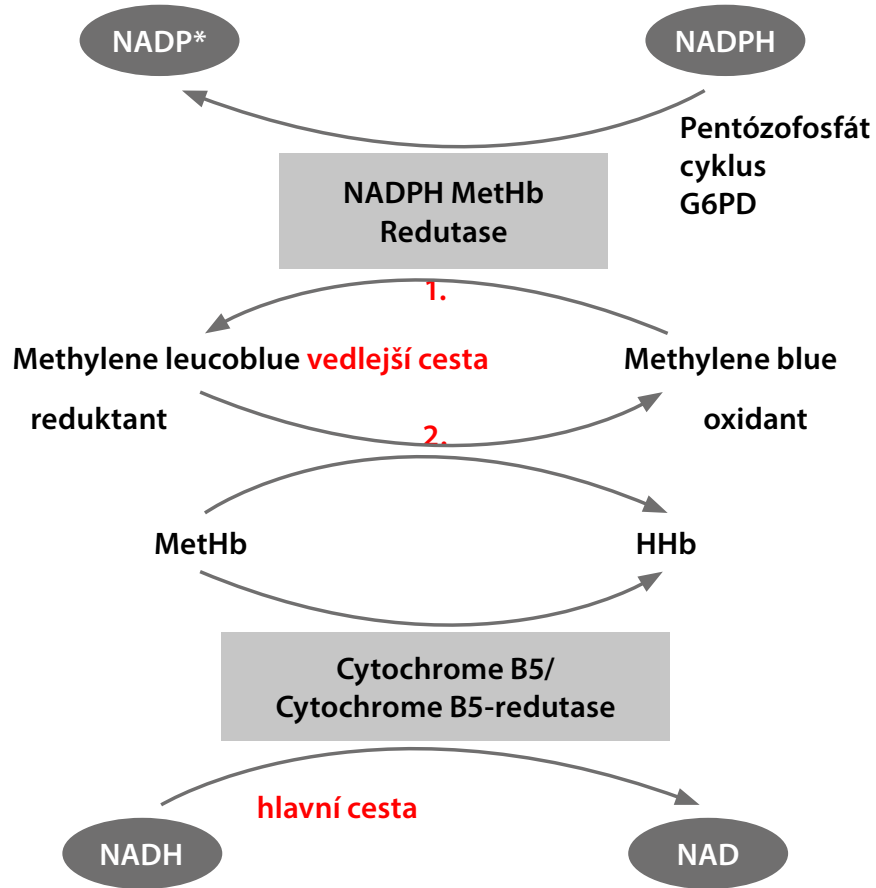

iont. V těchto případech je dědičnost autozomálně dominantní. Cyanóza je prítomná brzy po porodu.

\section{Získaná methemoglobinemie}

Získaná methemoglobinemie vzniká v důsledku přetižení redukční kapacity výše uváděných enzymů. Prričinou mohou být některé léky (Tab. 1) či toxiny. Z toxinů se jedná nejčastěji o dusitany (či dusičnany - ty jsou ve střevě redukovány pưsobením bakterií na dusitany) pocházející z hnojiv, chemických postřiků a odpadních vod, či anilinová barviva. K methemoglobinemii jsou nejnáchylnější děti do 6 měsíců v důsledku snižené jaterní syntézy methemoglobin-reduktázy (5). K prevenci nadměrné expozici dusitany a dusičnany jsou v ČR nastaveny prísné limity pro pitnou vodu (dusitany $0,5 \mathrm{mg} / \mathrm{l}$ a dusičnany $50 \mathrm{mg} / \mathrm{l}$ ).

\section{Lokální anestetika jako přičina methemoglobinemie}

V literatuře jsou opakovaně popsány kazuistiky a série prípadů závažných methemoglobinemií po aplikaci lokálních/topických anestetik (LA). Velké soubory ukazují incidenci methemoglobinemie 0,035-0,15\% pacientů podstupujících zákrok s lokální anestezií $(6,7)$. Z dostupné literatury jednoznačně plyne, že riziko methemoglobinemie se mezi jednotlivými preparáty liší. Nejvyšší riziko je spojeno s esterovým LA benzokainem. Námi použité LA Mesocain (trimecain) patří do modernější skupiny amidových lokálních anestetik, která mají výskyt Nú nižší. Nicméně i amidové LA prilokain a v menší míre i subkutánně podávaný trimecainu chemicky velmi podobný lidokainu jsou s methemoglobinemií spojovány $(8,9)$. Data pro trimecain nejsou ve světové literatuře k dispozici.

Rizikovými faktory rozvoje methemoglobinemie jsou hospitalizace v době výkonu a systémová infekce, které obě zvyšují riziko methemoglobinemie až 10 krát $(6,8)$, anémie zvyšují riziko 1,9krát (6). Sepse výrazně zvyšuje uvolňování oxidu dusného. NO vede k produkci methe- 


\section{Vývoj methemoglobinemie $\mathbf{v}$ čase}

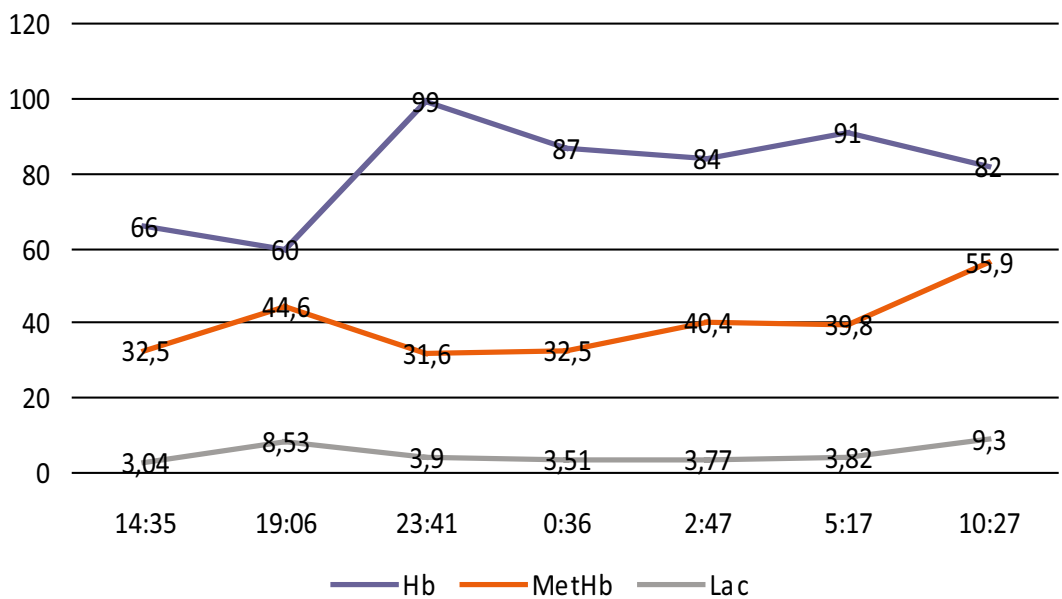

\begin{tabular}{|l|l|c|c|c|c|c|c|c|c|}
\hline & & $\mathbf{2 3 . 4 .}$ & & & $\mathbf{2 4 . 4}$ & & & \\
\hline & & $\mathbf{1 4 : 3 5}$ & $\mathbf{1 9 : 0 6}$ & $\mathbf{2 3 : 4 1}$ & $\mathbf{0 : 3 6}$ & $\mathbf{2 : 4 7}$ & $\mathbf{5 : 1 7}$ & $\mathbf{1 0 : 2 7}$ & $\mathbf{1 8 : 0 0}$ \\
\hline $\mathbf{p O}_{\mathbf{2}}$ & $\mathbf{k P a}$ & 11,4 & 9,49 & 26,1 & 23,92 & 26,22 & 20,59 & $?$ & \\
\hline $\mathbf{s a t} \mathbf{O}_{\mathbf{2}}$ & $\%$ & 99,5 & 99,5 & 100 & 99,5 & 99,5 & 99,5 & 99,3 & \\
\hline $\mathbf{H b}$ & $\mathbf{g} / \mathbf{l}$ & 66 & 60 & 99 & 87 & 84 & 91 & 82 & \\
\hline MetHb & $\%$ & 32,5 & 44,6 & 31,6 & 32,5 & 40,4 & 39,8 & 55,9 & \\
\hline Lac & $\mathbf{m m o l} / \mathbf{l}$ & 3,04 & 8,53 & 3,9 & 3,51 & 3,77 & 3,82 & 9,3 & \\
\hline
\end{tabular}

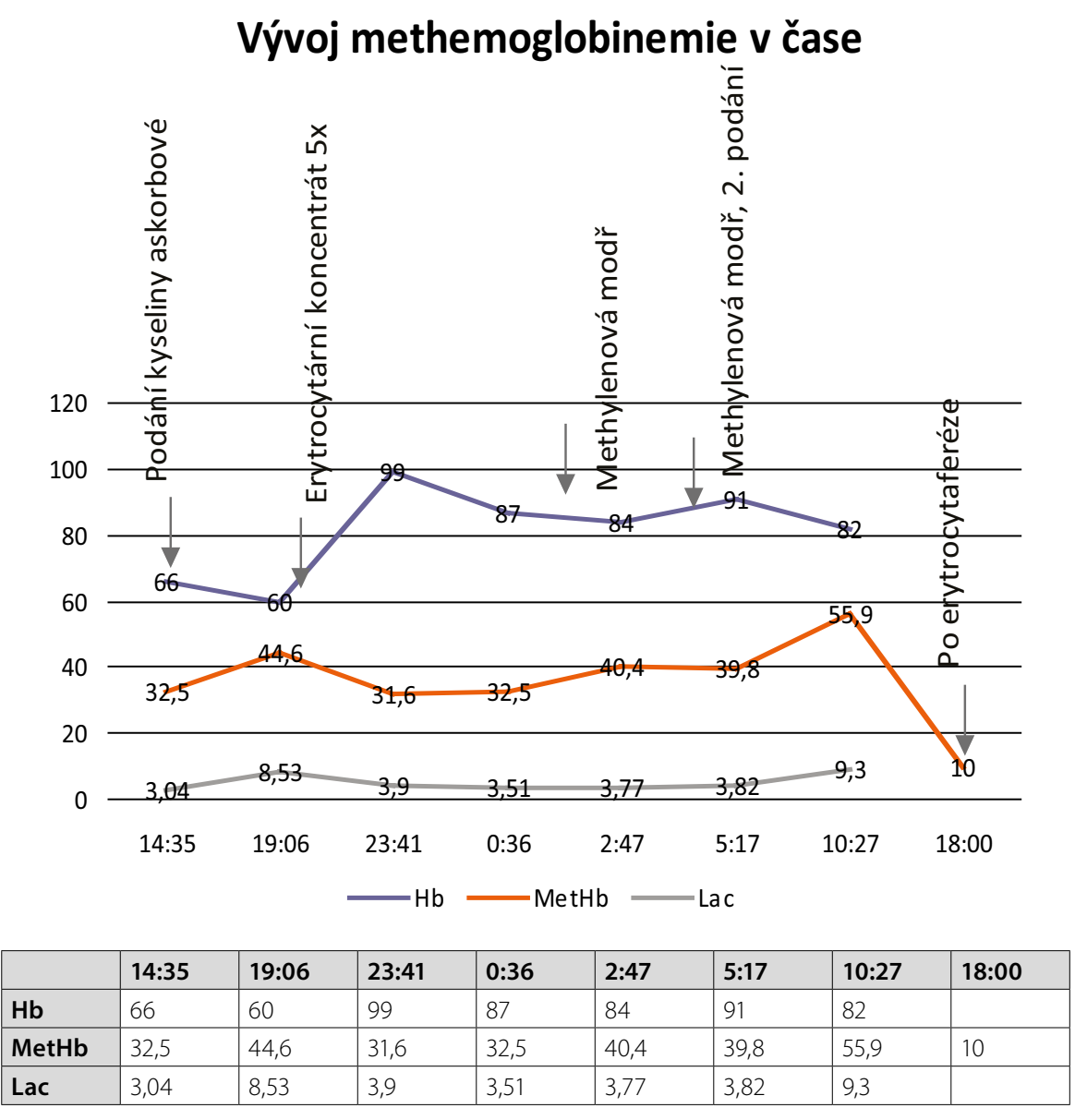


Tab. 1. Léky vyvolávající methemoglobinemii (volně dle (29))

\begin{tabular}{|l|l|}
\hline Analgetika a antipyretika & fenacetin, acetaminofen (paracetamol), fentanyl, celecoxib \\
\hline Antikonvulziva & fenobarbital, fenitoin, valproát \\
\hline Antiinfektiva & sulfonamidy, dapson, clofazimin, nitrofurantoin, chlorochine, primaquine, rifampicin \\
\hline Psychofarmaka & trazodon \\
\hline Vazodilatačně působící léky & nitroglicerin, izosorbid-dinitrát, nitroprusid sodný, oxid dusný \\
\hline Vitaminy & vitamin K3 \\
\hline Topická anestetika & benzokain, lidocain, prilocain \\
\hline Ostatní & $\begin{array}{l}\text { metylenová modř (ve velkých dávkách nebo u jedinců u deficitem G6PD), metoslopramid, rasburikáza, plody bobu } \\
\text { obecného (Vicia Faba) }\end{array}$ \\
\hline
\end{tabular}

Tab. 2. Přiznaky methemoglobinemie (volnè dle (30))

\begin{tabular}{|l|l|}
\hline $\begin{array}{l}\text { koncentrace } \\
\text { methemoglobinu v } \%\end{array}$ & symptomy \\
\hline pod $10 \%$ & bez př́znaků \\
\hline $10-20 \%$ & cyanóza, hnědé zbarvení kůže \\
\hline $20-30 \%$ & $\begin{array}{l}\text { úzkost, únava, bolesti hlavy, světloplachost, } \\
\text { tachykardie }\end{array}$ \\
\hline $30-50 \%$ & únava, zmatenost, nevolnost, tachypnoe \\
\hline $50-70 \%$ & koma, kreče, maligní arytmie, acidóza \\
\hline $70 \%$ a více & smrt \\
\hline
\end{tabular}

moglobinu (10). Vliv kardiálních a plicních komorbidit je ještě menší (6). Dopad renální insuficience se v jednotlivých studiích liší $(6,7)$. U naší pacientky byly splněny obě nejrizikovější podmínky.

\section{Hemodialýza a methemoglobinemie}

Ve světové literatuře je uváděno několik prípadů, kdy se u pacientů na hemodialýze (HD) vyvinula methemoglobinemie. U ambulantních pacientů na domácí dialýze byla prričinou kontaminace vody v domácím zdroji, nejčastěji ve studni (11). U hospitalizovaných pacientů na kontinuální náhradě funkce ledvin byla jako př́čina identifikována neadekvátní clearance chloraminu z vodovodního řadu $(12,13)$. Řešením byla v obou prípadech výměna filtru. U nás na JIP filtr měněn nebyl a ani u nikoho s předchozích či následujících pacientů se klinické známky methemoglobinemie nerozvinuly.

\section{Projevy methemoglobinemie}

Klinické projevy methemoglobinemie jsou závislé na hladině methemoglobinu. Prvním projevem je modré či modrohnědé zbarvení kůže. Methemoglobin, na rozdíl od jasně červeného hemu, je totiž tmavý, což dává krvi, v závislosti na koncentraci, namodralou až čokoládově hnědou barvu. U lehčích, predevším vrozených, poruch se jedná o jedinou klinickou známky. Pokud je porucha vrozená, může být toto zbarvení kủže trvalé. Z oblastí s vysokou prevalencí RCM jsou známy celé "modré rodiny".

S narůstající koncentrací methemoglobinu se začínají projevovat i symptomy z tkáňové hypoxie (Tab. 2).

\section{Terapie}

Základem léčby methemoglobinemie je ukončení účinku vyvolávajícího agens, nejčastěji se totiž setkáme se získanou methemoglobinemií. Léčbou první volby je podání metylenové modři (methylthioninium chloride) a donorů elektronů (kyselina askorbová, riboflavin), které mohou pomoci cestou NADPH methemoglobinreduktázy zbavit se organizmu nadbytku methemoglobinu. Terapie má být zahájena u symptomatických pacientů s hladinou > 20\% MetHb, u asymptomatických > 30\% MetHb (14).

\section{Kyselina askorbová}

Kyselina askorbová je silné redukční činidlo a účastní se celé řady enzymových reakcí. Nabízí se proto jako ideální terapeutická možnost methemoglobinemie. Není překvapivé, že se v této indikaci používá již od poloviny minulého století (15). Dávkování u methemoglobinemie není ustálené a jednotlivé studie nabízí různá dávkovací schémata (300 mg/ kg i.v. bolus, 300 mg i.v. během 24 hod, a $10 \mathrm{~g}$ i.v. IV během 6 hod) (16).

Stejně jako dávkování, není zcela jasná ani pozice kyseliny askorbové v terapeutickém algoritmu. Lékem první volby je u RCM I. typu, kdy veškerý požadovaný efekt je „kosmetické“ odstranění cyanózy. V literatuře existuje vesměs shoda, že může být lékem volby pro získanou methemoglobinemii v regionech či subpopulacích, kde je vysoká prevalence deficitu G6PD, pro riziko hemolytické anemie po podání metylenové modři těmto pacientům (viz dále) či u pacientů s renální insuficiencí a těhotných (17). Ve kterých situacích by již kyselina askorbová neměla být použita jako lék volby, není presně známo. Dle některých autorů by to mělo být určeno klinickým stavem pacienta (18), jiné zdroje udávají cut off limity $20 \%$ methemoglobinu + prítomnost symptomů (19) či $30 \%$ methemoglobinu bez ohledu na symptomy (20).

\section{Metylenová modř}

Metylenová modř je obecně akceptována jako terapie volby pro většinu pacientů. Pomocí NADPH-methemoglobin reduktázy je redukována na leukomethylenovou modř. Ta dále vystupuje jako donor elektronů, což vede $\mathrm{k}$ redukci methemoglobinu na hemoglobin.

K přeměně methylenové modři na leukomethylenovou modř je třeba koenzym NADPH vznikající při metabolismu glukózy pentózofosfátovou drahou (ve které je G6PD prvním a rychlost limitujícím enzymem). To je důvodem, proč metylenová modř u pacientů s deficitem G6PD nejen nefunguje, ale může sama vést k hemolýze či methemoglobinemii (de novo vznikající či prohloubení preexistující methemoglobinemie). Methemoglobinemie indukovaná metylenovou modrí dle dostupných literárních údajů reaguje na podání kyseliny askorbové (21).

Doporučené dávkování je 1-2 mg/kg tělesné hmotnosti podávané krátkou 5 minutovou infuzí. Dávku je možné po hodině opakovat při prípadě rekurentních či perzistujících symptomů, nebo pokud methemoglobin zůstává výrazně zvýšený (22). 


\section{Hyperbarická terapie}

Je dle mnoha autorů řazena mezi alternativní metody terapie methemoglobinemie, nicméně přesvědčivá data o její účinnosti stále chybí $(23,24)$. HBO redukuje koncentraci methemoglobinu, dle některých údajů, o $8 \%$ za h (25).

\section{Výměnná erytrocytaferéza}

Výměnná erytrocytaferéza je rescue postupem v prípadech, kdy je terapie MM kontraindikována, není dostupná či selhala. V literatuře jsou na toto téma dostupná pouze kazuistická sdělení vesměs s př́iznivým výsledkem. Po nahrazení pacientových erytrocytů dárcovskými klesá MetHb na hodnoty blízké 0, a pokud nedojde k opakovanému pưsobení oxidačního činidla, je stav vyřešen (26-28).

\section{LITERATURA}

1. Bradberry SM. Occupational methaemoglobinaemia mechanisms of production, features, diagnosis and management including the use of methylene blue. Toxicol Rev 2003; 22: 13-17.

2. Song P, Li X, Yan Y. Analysis of the literature on acute aromatic amino or nitro-compounds poisoning. Zhonghua Lao Dong Wei Sheng Zhi Ye Bing Za Zhi 2014; 32: 366-369. 3. Shatila W, Verma A, Adam S. Plasmapheresis in severe methemoglobinemia following occupational exposure. Transfusion and Apheresis Science 2017; 56: 341-344.

4. Souza do Nascimento T, Otávio Lami Pereira R, Luiz Dias de MelloH, et al. Methemoglobinemia: from diagnosis to treatment. Rev Bras Anestesiol 2008; 58: http://dx.doi org/10.1590/S0034-70942008000600011

5. Richard Alyce M, Diaz James H, Kaye AD. Reexamining the Risks of Drinking-Water Nitrates on Public Health. The Ochsner Journal 2015; 14: 392-398.

6. Gian M, Novaro MD, Herbert D, et al. Benzocaine-induced methemoglobinemia: Experience from a high-volume transesophageal echocardiography laboratory. J Am Soc Echocardiogr 2003; 16: 170-175.

7. Kane GC, Hoehn SM, Behrenbeck TR, et al. Benzocaine-Induced Methemoglobinemia Based on the Mayo Clinic Experience From 28478 Transesophageal Echocardiograms: Incidence, Outcomes, and Predisposing Factors. Arch Intern Med 2007; 167: 1977-1982.

8. Mutlu M, Erduran E, Aslan Y. Acquired methemoglobinemia in infants. Turk J Haematol 2011; 28: 131-134.

9. Barash M, Reich KA, Rademaker D. Lidocaine-induced methemoglobinemia: a clinical reminder. J Am Osteopath Assoc 2015; 115: 94-98.

10. Ohashi K, Yukioka H, Hayashi M, et al. Elevated methemoglobin in patients with sepsis. Acta Anaesthesiol Scand 1998; 42: 713-716.

11. Carlson DJ, Shapiro FL. Methemoglobinemia from Well Water Nitrates: A Complication of Home Dialysis. Ann Intern Med 1970; 73: 757-759.

12. de Torres JP, Strom JA, Jaber BL, et al. Hemodialysis-associated methemoglobinemia in acute renal failure. Am J Kidney Dis 2002; 39: 1307-1309.

13. Medarov BI, Pahwa S, Reed S, et al. Methemoglobinemia Caused by Portable Dialysis in the Critically. Crit Care Med 2017; 45: e232-e235.

14. Skold A, Cosco DL, Klein R. Methemoglobinemia: pathogenesis, diagnosis, and management. South Med J 2011; 104: 757-761.

15. Sievers RF, Ryon JB. Congenital idiopathic methemoglobinemia: favourable response to ascorbic acis therapy. Arch Intern Med (Chic) 1945; 76: 299-307. doi:10.1001/archinte.1945.00210350045007

\section{Plazmaferéza}

Ačkoli v současné době chybí indikace plazmaferézy v terapii methemoglobinemie, může být rescue postupem v odstranění oxidačního činidla, odstranění volného hemoglobinu a tím umožní přerušení intravaskulární hemolýzy

\section{Závĕr}

Cílem článku je upozornit na vzácný, avšak potenciálně fatální nežádoucí účinek běžně užívaných léků. Pokud je methemoglobinemie zavčas rozeznána a je dostatečně energeticky postupováno, je většinou rychle a efektivně léčitelná metylenovou modří. Ve vzácných prípadech však pacienti na iniciální léčbu nereagují a je třeba použít některé z rescue postupů. S jejich aplikací je však v českých podmínkách minimum zkušeností.

16. Cortazzo JA, Lichtman AD. Methemoglobinemia: a review and recommendations for management. J Cardiothorac Vas Anesth 2014; 28: 1043-1047.

17. Faust AC, Guy E, Baby N. Local Anesthetic-Induced Methemoglobinemia During Pregnancy: A Case Report and Evaluation of Treatment Options. J Emerg Med 2018; 54: 681-684. 18. Wright RO, Lewander WJ, Woolf AD. Methemoglobinemia: etiology, pharmacology, and clinical management. Ann Emerg Med 1999; 34: 646-656.

19. Toker I, Yesilaras M, Tur FC, et al. Methemoglobinemia caused by dapsone overdose: Which treatment is best? Turk J Emerg Med 2016; 15: 182-184.

20. Waller HD, Benöhr HC, Tigges FJ. On the mechanism of ascorbic acid induced methemoglobin reduction of human erythrocytes. Klin Wochenschr 1977; 55: 955-964.

21. Balwani MR, Bawankule CP, Ramteke V, et al. Methylene Blue Induced Methemoglobinemia with Acute Kidney Injury in a Glucose-6-Phosphate Dehydrogenase-deficient Patient. Indian J Nephrol 2017; 27: 465-467.

22. Methylthioninium chloride Proveblue $5 \mathrm{mg} / \mathrm{ml}$ solution for injection, SPC, dostupné z https://www.ema.europa.eu

23. Prchal JT. Clinical Features, Diagnosis, and Treatment of Methemoglobinemia. UpToDate Web site http://www.uptodate.com/contents/clinical-features-diagnosis-and-treatment-of-methemoglobinemia; Accessed 12.02.14

24. Hoffman RS, Nelson LS, Howland MA (eds.). Goldfrank's Manual of Toxicologic Emergencies. The McGraw-Hill Companies, Inc; 2007: 977-985.

25. Hunter L, Gordge Ldargan PI, Wood DM. Methaemoglobinaemia associated with the use of cocaine and volatile nitrites as recreational drugs: A review. $\mathrm{Br} J$ Clin Pharmacol 2011; 72: 18-26.

26. Patnaik S, Natarajan MM, James EJ, et al. Methylene blue unresponsive methemoglobinemia. Indian J Crit Care Med 2014; 18: 253-255.

27. Lockhart V, Ong M. 367 Red Blood Cell Exchange for Treatment of Acquired Methemoglobinemia in a Hospitalized Patient: A Case Report. American Journal of Clinical Pathology 2018; 149: S159-S160.

28. Khetarpal A, Kotwal U. Role of Automated Therapeutic Red Cell Exchange in the Setting of Acute Methemoglobinemia: Our Experience. Indian J Hematol Blood Transfus 2018; 34: 143-145.

29. Alanazi M. Drugs may be Induced Methemoglobinemia. Journal of Hematology \& Thromboembolic Diseases 2017; 10.4172/2329-8790.1000270.

30. Mark Barash DO, Keith AR, Rademaker D. Lidocaine-Induced Methemoglobinemia: A Clinical Reminder. The Journal of the American Osteopathic Association 2015; 115: 94-98. 